\title{
The Role Corporate Governance in Foreign Direkt Investment in Kosovo
}

\author{
Mr. Sc. METË BEQIRAJ, PhD (c)
}

Kosovo Energetic Corporation J.S.C.

m beqiraj_1@hotmail.com

\begin{abstract}
Good corporate governance (CG) ensures transparency which makes Kosovo more attractive and valuable for investors or buyers. The transition to a market economy and private ownership transfer issue highlights the CG in Kosovo. This created the prerequisites for the creation of a new system of legal framework and thus a new model CG. The purpose of this paper is to inform interested parties by offering favors of Kosovo for investment. In addition to the literature, for this paper research various reports and data of Kosovo institutions were used and publications of this field online. Kosovo has good potential to offer prospects for foreign direct investment (FDI). FDI in Kosovo are very important for a sustainable economic growth. Government of Kosovo, supported by the international community has made continuous efforts to create an enabling environment and favorable investment. However, lack of law enforcement, high level of corruption, the judiciary and other factors affecting Kosovo has failed to be an attractive place for attracting FDI.
\end{abstract}

Keywords: corporate governance, foreign direct investment, Kosovo.

\section{Introduction}

CG in Kosovo is a new concept and is in continuous process of development and improvement. If countries want to reap the full benefits of the global capital market, and if they are to attract long-term capital, the actors must believe and understand the CG across borders (OECD, 1999: 10). "Good CG helps to bridge the gap between the interests of those who manage a company and the shareholders who own it, increasing the confidence of investors and making it easier for companies to raise equity capital and finance the process investment. Good CG also helps ensure that a company engages and respects its own laws and forms of value in establishing relationships with stakeholders, including employees and creditors "(OECD, 2013). CG makes companies more accountable and transparent to investors and gives them the tools to respond to the concerns of stakeholders. CG also contributes to development. Increasing access to capital encourages new investment, stimulate economic growth, and offers employment opportunities (IFC, 2014). Good CG ensures transparency which makes companies more attractive and valuable for investors or buyers.

CG is a concept and very actual topic as for enterprises, corporations, banks and the importance that is taking this concept comes as a result of recent developments and changes that have occurred globally, such as: the increasing number of privatizations, the spread of largest shareholder investment and global integration of financial markets arise from the need for a convergence towards a common set of rules and practices the same in different countries.

Good CG provides security for owners, investors and lenders that their interests are protected in the company and helps the company access to external sources of financing. Experience shows that the lack of a good CG discourages domestic and foreign investors and thus slowing down the evolution of ownership and contributes to economic stagnation. CG, especially one that is transparent, it is gaining importance and is becoming more appreciated. CG is not only an essential element in increasing the confidence of investors, promote competition and improve economic growth in the national context, but also in the international importance (Llaci \& Tabaku, 2009).

OECD experience has shown that good CG is an important prerequisite for effective privatization of companies and makes them more attractive to prospective buyers, and increases their market value. Research and experience show that investors evaluate companies CG up good and healthy. The transition to a market economy and private ownership transfer issue highlights CG in Kosovo. This created the prerequisites for the creation of a new system of legal framework and thus a new model of CG. Countries in transition have begun ambitious reforms aiming to create an enabling environment for private sector development, including the liberalization of trade and investment policy, measures to strengthen the financial sector 
and to encourage the growth of exports, growth technological progress and attracting foreign investment. The results of these reforms are reflected in increased investment, productivity, income and exports, as well as attracting financial markets. However, those countries in transition that have made significant strides in improving the business environment in general cannot expect the fruits of these reforms if they are not in accordance with the rules established in the CG standards and practices.

CG is an important element in the process of investment, mobilization, allocation and monitoring of efficient use of resources and its effectiveness provides a healthy basis for economic growth (Nestor, S., Yasui, T., \& Guy, ML).

\section{Kosovo's economy and foreign direct investment}

Kosovo has a young and dynamic economy. It has been transformed from a centralized planned economy to an open market economy, which experienced its profound transformation after 1999 with the liberation of Kosovo from Serbia. One of the challenges it faced during the last decade is the process of privatization. In an effort to create a more suitable environment for investors, the PAK (Privatization Agency of Kosovo) continues with a program to accelerate the privatization of enterprises and assets through a transparent and competitive bidding, according to international best practices. This process is attractive to investors because it enables the new owner to make immediate investments and make new power line workers, offering clean owned no inherited debt without interference from creditors and potential claimants.

Situated in South Eastern Europe, Kosovo's economy has become part of the region's economic integrations, which provide opportunities for market expansion in a very wide area. An aim in itself is already the increase of competitiveness of the economy by increasing its exporting capacity to reduce the trade deficit Kosovo currently has. As an important location for business development Kosovo offers a range of comparative advantages such as: a young and very qualified population, where the average age is very young, natural resources, favorable climate conditions, new infrastructure, fiscal policy with the lowest taxes in the region, geographical location with access to the CEFTA and the European Union regional market. In addition to being a member of CEFTA, in June this year Kosovo has joined the IMF (International Monetary Fund) and WB (World Bank) and aspires to join other powerful economic and financial mechanisms such as EBRD, World Trade Organization (WTO etc.).

\subsection{Vital Economic Statistics}

- No of Inhabitants: 1.8 million

- Surface Area: $10,908 \mathrm{~km}^{2}$

- GDP: 5.02 billion $€$ (2012 est.)

- $\quad$ GDP economic growth rate: $4.0 \%$ (2012 est.)

- GDP per capita: $2750 €(2012$ est.)

- GDP - by sector: agriculture $20 \%$, industry $20 \%$, services $60 \%$

- Unemployment rate around $40 \%$

- Inflation Rate: 3.5\% (2012)

- $\quad$ Foreign direct investment, FDI: 232.0 million euro (2012)

\section{Trade Exchange}

- $\quad$ Exports: 295.0 million $€(2012)$

- Main export partners: Italy (25.8\%), Albania (14.6\%), Macedonia (9.6\%), Switzerland (5.5\%), Germany (5.4\%), Serbia (5.4\%), Turkey (4.1\%), China (1.2\%)

- Exported Goods: processed goods (56\%), unprocessed materials (25\%), food and live animals $6 \%$, fuel $4 \%$, machinery and transport equipment (3\%), etc.

- Imports:: 2.507 billion $€(2012)$ 
- Main import partners: Germany (12.1\%), Macedonia (11.5\%), Serbia (11.1\%), Italy (8.5\%), Turkey (8.0\%), China (6.4\%), Albania (4.4\%), Switzerland $(0.9 \%)$,

- Imported Goods: machinery and transport equipment (21\%), processed goods (20\%), fuel (16\%), food and live animals (16\%), chemical products (10\%) etc.

- $\quad$ Natural Resources: lignite, zinc, lead, ferronickel and agricultural arable land.

- Currency: EURO

\section{Kosovo Trade Exchange}

During 2012 Kosovo reached a value of about 2.8 billion euro in trade exchanges. Regarding the Kosovo's export and import, main trading partners are the EU countries with the participation of about $39 \%$ for export and about $39 \%$ for import, as well as CEFTA countries which participate with 37\% for export and 34\% for import to total 2012.

In terms of exports to Kosovo with Balkan countries, Albania participates with $14.6 \%$, Macedonia $9.6 \%$, Serbia with $5.4 \%$ compared with the 2012 total, while greater participation of imports in Kosovo from the Balkan countries are Macedonia with $11.5 \%$, Serbia $11.1 \%$ and Albania with $4.4 \%$, Table 1.

Table 1: Main partners of Kosovo in export and import for 2012

\begin{tabular}{|c|c|c|c|c|}
\hline Countries & Export $(000) €$ & $\begin{array}{l}\text { Participation \% in } \\
\text { the total }\end{array}$ & Import $(000) €$ & $\begin{array}{l}\text { Participation \% in the } \\
\text { total }\end{array}$ \\
\hline Italy & 71.351 & 25.8 & 213.469 & 8.5 \\
\hline Albania & 40.180 & 14.6 & 110.528 & 4.4 \\
\hline Macedonia & 26.376 & 9.6 & 287.739 & 11.5 \\
\hline Switzerland & 15.133 & 5.5 & 22.664 & 0.9 \\
\hline Germany & 14.995 & 5.4 & 304.195 & 12.1 \\
\hline Serbia & 14.968 & 5.4 & 278.388 & 11.1 \\
\hline Turkey & 11.380 & 4.1 & 199.881 & 8.0 \\
\hline China & 3.266 & 1.2 & 159.651 & 6.4 \\
\hline Total & 276.100 & 71.6 & 2.507 .609 & 62.9 \\
\hline
\end{tabular}

Source: Ministry of Foreign Affairs of Kosovo, Economy and Investments in Kosovo. http://www.mfa-ks.net/?page=1,119 


\section{The importance of foreign investment in Kosovo}

Reasons to invest in Kosovo - Benefits for potential foreign and local investors. Some of the benefits from investing in Kosovo are: low taxes, rich resources and supportive business environment.

- Taxes in Kosovo are very low compared to neighboring countries,

- The tax system is kept extremely simple,

- The population - young and motivated, $70 \%$ under the age of 35 ,

- A young and motivated workforce with strong entrepreneurial skills and spirit and also general knowledge of most European languages,

- Enviable natural resources: coal, zinc, lead, faro-nickel and fertile agricultural land,

- Free access to European Union market and neighboring markets,

- Modern institutions in support of businesses,

- Simple and quick procedure for business registration (within 3 days),

- Secure banking system,

- $\quad$ Modern legal structure and in accordance with the EU, and

- The official currency is the Euro, which eliminates the risk of Euro-zones.

After its independence, Kosovo has made great progress in many areas of its development such as: increasing political stability, raising the level of security, stable economy with continuous growth, completion of legislation etc. It has become an important part of regional cooperation initiatives, through which the creation of a common regional market is achieved, as well as the elimination of customs tariffs, elimination of trade barriers, and opening new perspectives. Kosovo institutions have worked and continue to work rapidly to meet the standards required for European Union membership.

A stable macroeconomic environment has been created, with a sound financial system, reforms were made in fiscal policy in the application of lower tax rates in the region. Among the important objectives that our country has set for itself is the increased competitiveness of the domestic economy in the regional market.

Progress has been achieved in the establishment of modern infrastructure, both within Kosovo and also in its connections with the region. It is worth mentioning here the connection with Albania through construction of a highway and commitments of Albania to build the railway line in the near future connecting these two countries. The importance of this route for Kosovo has double meaning, considering that Kosovo already has its Adriatic port through which it is connected with sea transport. Through this route Kosovo is connected to its port at a time distance of only two and a half hours. Soon the construction of highways that connect Kosovo with Albania, Macedonia and Serbia will begin, which represents a very favorable opportunity for foreign investors.

Our country offers great opportunities for investment in other sectors such as: agriculture, energy, viticulture, tourism, extraction and processing of metals, etc. Business registration system in Kosovo is another important factor stimulating the growth of investment, with simplified procedures, and quick registration of new businesses for a short time.

All these point to Kosovo as a very attractive country with investment opportunities for any investor of different sectors, such as in privatization where privatization and concession granting of large public companies is expected such as Post and Telecom of Kosovo and the Power Distribution System as well as investment in green fields. In the latter, very favorable opportunities are offered in the provision of physical infrastructure by industrial parks. Kosovo is working on creating a financial capital market, which would offer an opportunity for investors who want to invest in shares of various companies. During year 2012 it is estimated that $€ 232$ million euro were invested, the total number of foreign companies operating in Kosovo amounts to about 5018.

Investments in the banking system represent greater financial value with foreign capital. Foreign capital has a wide geographical distribution, from more than 80 countries of the world, where Albania ranks first in number of registered businesses. 
Table 2: Distribution of foreign investment companies by sectors of economy

\begin{tabular}{|llll|}
\hline No & Sector & No. Of Companies & $\%$ in total \\
\hline $\mathbf{1 .}$ & Trade & 1952 & $\mathbf{3 8 . 9 \%}$ \\
\hline $\mathbf{2 .}$ & Production & 791 & $\mathbf{1 5 . 8 \%}$ \\
\hline $\mathbf{3 .}$ & Service activities & 764 & $\mathbf{1 5 . 2 \%}$ \\
\hline $\mathbf{4 .}$ & Construction & 607 & $\mathbf{1 2 . 1 \%}$ \\
\hline $\mathbf{5 .}$ & Tourism and Hotels & 350 & $\mathbf{7 . 1 \%}$ \\
\hline $\mathbf{6 .}$ & Transport & 181 & $\mathbf{3 . 6 \%}$ \\
\hline $\mathbf{7 .}$ & Financial sector & 141 & $\mathbf{2 . 8 \%}$ \\
\hline $\mathbf{8 .}$ & Telecommunications & 121 & $\mathbf{2 . 4 \%}$ \\
\hline $\mathbf{9 .}$ & Health services & 68 & $\mathbf{1 . 3 \%}$ \\
\hline $\mathbf{1 0 .}$ & Education & 43 & $\mathbf{0 . 8 \%}$ \\
\hline \hline & Totali & $\mathbf{5 0 1 8}$ & $\mathbf{1 0 0 \%}$ \\
\hline
\end{tabular}

Source: Ministry of Foreign Affairs of Kosovo, Economy and Investments in Kosovo. http://www.mfa-ks.net/?page=1,119

\section{Foreign Direct Investment (FDI) in Kosovo}

Foreign direct investment in Kosovo represents one of the components that is important for economic growth and new sources of financing in the country. Given the improved business climate, stable macroeconomic environment and excellent opportunities in all sectors of the business, Kosovo is becoming a more attractive place to do business. As a result, the interest of foreign investors has grown steadily in recent years. During these years, the economy of Kosovo has been a satisfactory level of FDI inflows which have had an average share of $7.6 \%$ of GDP. Kosovo during the past seven years on average has attracted FDI worth 335 million euro per year, or 2,345.9 billion Euros in the last seven years, the figure 1. Foreign direct investment according to the Central Bank of Kosovo (CBK) mainly belong form of capital investment in 2012, while on a sectoral basis, FDI had constant changes in participation (CBK, 2013). As shown, FDI in associates during 2012 have increased the real estate sector, while other economic sectors as the financial sector and transport and communications decreased in recent years. FDI significant increase observed in the construction sector and the manufacturing sector as a share has shown a positive trend in stability in recent years. In terms of countries, FDI in Kosovo mainly come from EU countries, and in recent years has increased the share of FDI from England and Turkey. It is worth mentioning that among the factors that mostly determine the level of FDI in Kosovo are considered to be economic growth in the euro zone as well as the privatization process in the country. The following figures show FDI by country and economic activity in the investment worth millions of Euros. 
Figure 1: Foreign direct investments in Kosovo

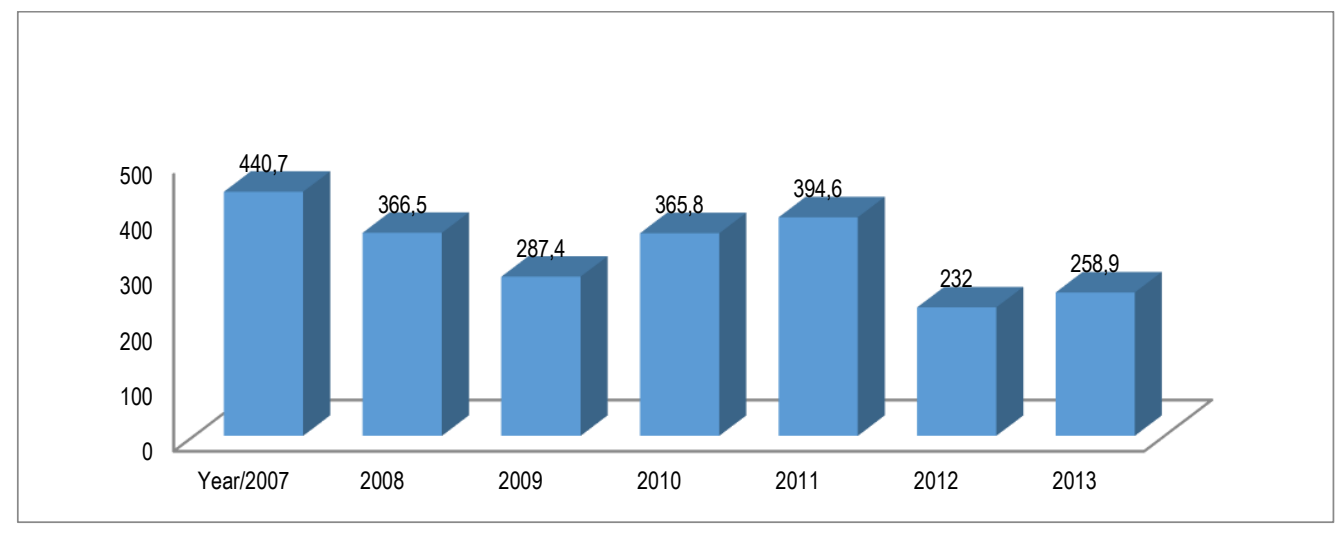

Source: Central Bank of Kosovo

Regarding the origin of FDI for 2013 (CBK, 2013), Turkey represents the first place that FDI comes (33.6\%), followed by Switzerland (16.1\%), Germany (8.4\%), Albania (7.9\%), etc. While investments in Turkey have increased by $32.3 \%$ during 2013, investment from Germany and Switzerland have decreased for 56.2 respectively $4.8 \%$. Also, it is worth noting that investments in Albania have tripled in 2013 compared with 2012.

FDI by the main economic sectors, show that the FDI in real estate have increased dominance in the structure of total FDI during 2013. With the growth of the sector are also characterized transport and telecommunications, financial services, energy and trade, while FDI in the sector construction and manufacturing declined in the structure.

\section{Conclusions}

Driven by technological change, global competition and liberalization of markets, FDI plays a key role in the process of global economic integration. FDI contributes to economic growth, especially for developing countries, as the case of Kosovo. FDI is the main source of external financing in developing countries as the case of Kosovo. FDI generate employment, raise productivity and new technology, increased exports, and contributes to long-term economic development of the country. FDI having a direct effect on the economy as a whole, the government should pay great importance to the design and implementation of policies that stimulate attract investors. To enhance the attraction of FDI, Kosovo needs improvements in the legal and institutional framework. Currently, the legal basis and the tax system are very aligned with the EU one, but still the implementation in practice remains a challenge. The issue lies in the implementation and operation in order to improve the climate for business and investment environment and increase investor confidence. Kosovo Government should provide standardized legal basis and guarantees protecting foreign investments.

Recently the government is committed to the development of infrastructure as an important factor for the further growth of FDI, in this respect there is progress in road infrastructure but there are delays in energy infrastructure especially in building new energy capacities. Kosovo Government should be committed, challenged and offer new opportunities for attracting FDI. Finally, political stability, lack of law enforcement, high level of corruption, the judiciary and other factors affecting Kosovo has failed to be an attractive place for attracting FDI.

\section{References}

[1] Central Bank of Kosovo

[2] IFC (2014): http://www.ifc.org/wps/wcm/connect/a14257004aadce2a92cdfeeec99f439e/CG+Fact+Sheet+3-1014.pdf?MOD=AJPERES 
[3] Llaci Sh. \& Tabaku J., (2009), Qeverisja e Korporatave, Tiranë.

[4] Ministry of Foreign Affairs of Kosovo, Economy and Investments in Kosovo.

[5] http://www.mfa-ks.net/?page=1,119

[6] Nestor, S., Yasui, T. \& Guy, M.L., The relevance of Corporate Governance to Euroasian transition Economies. http://www.oecd.org/corporate/ca/corporategovernanceprinciples/1930716.pdf

[7] OECD, (1999). Principles of Corporate Governance, OECD, Paris.

[8] OECD, (2013). Corporate Governance and Capital Markets in Eurasia: Two Decades of Reform, OECD, Paris, 2013. 